\title{
THE EUROPEAN COURT OF JUSTICE: OF INSTITUTIONS AND DEMOCRACY
}

\author{
Martin Shapiro*
}

\section{Constitutional Courts}

The problem of democracy and judicial review is a problem engendered by successful constitutional courts. For where courts are not successful in establishing veto powers over legislation, no problem or only a very limited problem occurs. Of course any court interpreting statutes in the process of applying them does some law making. ${ }^{1}$ How much this law making interferes with democracy depends on how easy it is for the legislature to legislate. Where legislatures can amend statutes easily, they can easily correct "errors" of judicial statutory interpretation. Judicial review of the lawfulness of administrative action essentially involves the same power of statutory interpretation with the same potential for legislative correction.

Most of the nations of the world that do not have successful constitutional courts are not democracies. Indeed, no state without considerable claims to democracy has successful judicial review. These facts are clues to the obvious. Constitutional government is limited government. In the real world we do not encounter nondemocratic limited governments although we encounter many shades of more or less democratic, more or less constitutional governments. So there is some affinity between democracy and constitutionalism. Unlike the one or the few, the people must believe either that they cannot or ought not engage in

* James W. and Isabel Coffroth Professor of Law, University of California at Berkeley.

1 This article is sparsely footnoted. Those who are not convinced by the argument on its face will hardly be convinced by a flood of footnotes. To those who believe that a single legal rule always exists out there somewhere which will yield a single correct, independent, neutral, just solution to whatever conflict is presented to the judge, the argument here is a contingent one. It applies only when judges do not seek the single rule and the correct answer but choose to make judgments on the basis of preferences. Those who believe that there are single correct rules and single correct legal answers and that judges always pursue them are excused reading what follows. For them it is simply nonsense with or without footnotes. 
unlimited government of themselves. Whether it is "cannot" or "ought not" seems, to me at least, a crucial question.

Successful constitutional courts essentially engage in two rather different sorts of jobs. One is to referee boundary disputes between parts of government in constitutional systems that divide power among parts of government. The other is to sustain "rights" against invasion by government action and/or (perhaps) inaction. There appears to be a general consensus that courts ought not to use their powers of constitutional judicial review to enact simply desirable new government programs or disestablish undesirable ones or to divide up resources among contending interests. Those who believe that constitutional courts can do no more or less than that are generally opposed to judicial review. For nearly every teacher of constitutional law there is the division of powers part and the rights part and maybe a few other miscellaneous bits and pieces.

Until recently we might have been quite confident that the really crucial part must be the division of powers part. For until recently only political systems of a federal or quasi-federal nature enjoyed successful constitutional judicial review. Of the post-World War II successful constitutional courts, in many ways the most surprising has been that of France. For we all knew that France, of all nations, would never tolerate the gouvernement des juges. France acquires judicial review when it constitutionally divides powers, not among geographic areas to be sure, but in its central government. But what of the rights part. The U.S. Supreme Court only began an active rights jurisprudence more than a hundred years after its founding. Of the post-World War II constitutional courts, the German Court did both division of powers and individual rights, but it could be argued that it was German federalism that compelled the Court's existence. The European Court of Justice clearly was a division of powers court which, like the French, only eventually discovered that it had "rights" jurisdiction. It was the Italian, Japanese and Israeli courts plus the European Court of Human Rights that could be argued to be evidence that rights could be an independent or even sole "cause" of successful review. Each of those courts, however, might not quite count for such a proposition. The Japanese Supreme Court need not really be considered a successful constitutional court. The Italian Constitutional Court may owe its success to its peculiar role as case-by-case de Fascification tribunal. That is, constitutional judicial review was chosen rather deliberately as an alternative to the wholesale winnowing of Fascist elements from the 
whole body of Italian law that the legislature appeared incapable of performing. The European Court of Human Rights indubitably was rights based, but owes its very existence to the desire to establish rights in a system of extreme political division of powers that is a sovereignty based international system. As to the Israeli Supreme Court, surely I should leave the causes of its constitutional success to others, and surely its constitutional law is basically about rights, not division of powers. But it may be so sui generis as not to be of much direct help in dealing with the general causes of successful constitutional review.

\section{Courts as Institutions ${ }^{2}$}

If for the moment, and for the sake of argument, we assume that the essential or organic connection is between division of powers and review, then we may pursue the theme that the people believed that they could not govern themselves rather than that they ought not. This view of constitutions as a contract between principals and agents is an old and now again fashionable one. In effect the argument runs that the people as principals contract with agents to run the government for them. The problem becomes how to enforce such a contract given the absence of any superior enforcing authority. There was the appeal to God or the right of revolution, but these were both uncertain and extreme remedies. It is a commonplace that where enforcement is uncertain, contracts should be written so as to be as self-enforcing as possible. Constitutional division of powers is a very clever self enforcement provision. It divides the agent into parts and sets each agent part to enforce the contract on the other agent parts. Each part's self interest in defending its own agent capacities works to enforce the contract on behalf of the principal.

To this commonplace argument about constitutionalism, let us add an argument about the nature of courts. When two persons fall into a conflict they cannot resolve for themselves, it is natural for them to turn

2 The institutional theory of constitutional judicial review courts presented here is derived from Martin Shapiro, Courts: A Comparative and Political Analysis (Chicago, 1981); Shapiro, “Judges As Liars”, (1994) 17 Harv. J. of Law and Public Policy 155; Wayne Sandholz and Alec Stone Sweet, eds., Supranational Governance: The Institutionalization of the European Union (forthcoming); Pierson, "The Path to European Integration: A Historical Institutionalist Approach", (1996) 29 Comparative Political Studies 123; Sweet, "Judicialization and the Construction of Governance", Comparative Political Studies (forthcoming). 
to a third person. Courts are instituted as third party conflict resolvers. In order to successfully resolve conflicts, the third party must appear neutral and independent vis-à-vis the two conflictors. Courts acquire the virtues of neutrality and independence by announcing that their decisions are based on a legal rule that pre-existed the conflict. In reality, because a legal rule that would yield a clear choice of winner and loser in a particular conflict does not always pre-exist, courts will necessarily make legal rules from time to time and pretend they preexisted the conflict which they are actually invented to resolve. Judicial review, that is the power of a court to veto statutes and/or administrative actions, is one form of this covert law making. A court exercising review finds a higher law rule under which a dispute about the validity of a lower law or decision may be resolved. Where no such rule exists the court makes it up while claiming otherwise.

Judicial review is a particularly precarious arena for this judicial pretence because the proportion of conflicts not actually falling under pre-existing legal rules is considerably higher in this arena than most others. Constitutions are likely to contain fewer specific, detailed, clear, pre-existing rules than are statutes. And new constitutional rules are usually less easily formally enacted than statutory rules. The entities at risk of falling into conflicts subject to constitutional resolution are likely to be very constitution conscious and to work hard to frame their lower laws or decisions in ways that avoid overt or obvious violations of the higher law. Thus constitutional courts are likely to find themselves frequently in the position of having to make new rules because no preexisting legal rule will resolve the conflict before them.

Put division of powers and judicial review together and we get the following. The people write a division of powers contract with the government so that it will be self-enforcing through the checking of each part of the agent by the others. One facet of this self-enforcing contractual mechanism is judicial review. Judicial review, however, is only one form of the general behavior of courts, the resolution of conflict through the announcement, and thus inevitably, the creation of legal rules. Thus, in choosing judicial review as one of the self-enforcing mechanisms of the contract of government, the principals have chosen to give higher law making power to one of their agents.

The constitutional theory sketched here is not only one of principal and agent but is also an institutional theory of the constitution. It asserts that although any set of constitution makers may to some degree invent new, sui generis institutional arrangements, for the most part 
they can and must choose among a menu or catalogue of culturally defined pre-existing institutions, that is well understood paradigmatic clusters of rules and regularities that define relatively fixed repertoires of behavior among actors pursuing relatively fixed roles. In simple English, those creating constitutions for the most part are forced to choose among such pre-defined political institutions as legislatures, elections, bureaucracies and so on. While they may "customize" each of these in various ways, and choose to structure their interactions in various ways, constitution makers cannot avoid choosing institutions that, once chosen, will act in ways characteristic of those institutions, ways that had been institutionalized before the particular set of constitution makers chose that particular institution.

The "junk yard dog" is a fierce dog kept confined during business hours and set loose to roam the junk yard all night attacking any and all interlopers. As to the owner of the junk yard who, for some reason, enters at midnight and comes to canine grief, there is a saying: "If you buy a junk yard dog ..." An institutional theory of constitutions argues that institutions like legislatures and courts have certain embedded behavior patterns that will come out no matter the constitution matrix in which they are inserted although, of course, they will be constrained by whatever constitutional matrix contains them. Thus, if the people choose judicial review courts, those courts will make constitutional law just as inevitably as dogs will bite. And courts unchained against interlopers may well bite the wrong person from time to time.

We have here Plato's classic problem of who guards the guardians or who watches the watchers. ${ }^{3}$ If the people as principal choose judicial review as a mode of enforcing the contract of government, they also choose to take the bitter with the sweet of the institution they have chosen. The paradox faced by the people is that in order to employ judges to police those to whom the people have assigned the power to govern, the people must surrender some power to govern to the judges. Some degree of law or policy making discretion is inherent in the institution of judicial review because some quantum of rule making is inherent in third part conflict resolution.

With more or less post-modern posturing and citation of the appropriate European gurus, the same point can be made in terms of "inter-

3 Martin Shapiro, Who Guards the Guardians: Judicial Control of Administration (Athens, Ga., 1988); Cappelletti, "The Mighty Problem of Judicial Review and the Contribution of Comparative Analysis", (1980) 53 S. Cal. L.R. 409. 
pretation". Constitutional judicial review requires that the behavior of government be set against rules stated in a constitutional text. In order to do this job, reviewing courts must interpret the text. Whoever interprets text to some degree makes the text. The paradox faced by the people is that in order to employ judges to interpret the contract through which they have assigned the power to govern, the people must surrender some power to govern to the judges. Some degree of law or policy making discretion is inherent in the institution of judicial review because some quantum of rule making is inherent in the interpretation of rules. ${ }^{4}$

Even if setting judges to enforce a division of powers contract necessarily entails some popular consignment of law making discretion to the judiciary, the assignment is contingent both as a whole and as to quantity. That is, subsequent to the initial consignment, the people may withdraw it or limit it. Indeed, in the initial consignment they typically will seek to limit it. If the people have chosen review as a device for limiting the power of others to govern, they will usually be interested in limiting the power of the judges as well. Either initially or subsequently part of this limitation may be provided by the language of the constitutional text. Such limitation is obviously subject to the problem that the judges become judges in their own case when they are called upon to enforce the text on themselves. Some of the limitation will usually be through various constitutional checks and balances in which other governors limit judicial governors in various ways. Courts come with built in institutional weaknesses as well as strengths. Lack of enforcement powers is a notorious weakness of courts. Typically, courts must depend on executive authorities physically to enforce their judgments. In the well-known phrase, judges have neither the purse nor the sword. Thus, just as a certain transfer of power is inherent to judicial review, a certain limitation on power is also inherent. Courts cannot do much governing without the assistance of others, and in more or less democratic states they are unlikely to be able to govern without popular support even as much as other parts of government could.

\section{Successful Constitutional Courts}

The question of the inherent limitations on judicial review can be put in a somewhat different way. How must a reviewing court in a division 
of powers constitutional system act in order to achieve success. ${ }^{5}$ I believe there are three keys to success.

\section{Judicial "Neutrality"}

The first is the judicial myth itself. Whatever authority courts have is piggybacked on their appeal as third party conflict resolvers. That appeal depends on their institutional reputation for neutrality and independence vis-à-vis the two conflicting parties. It is widely understood that such neutrality and independence are not free standing. Courts are courts of law. They are not supposed to be neutral and independent vis-à-vis the law. Quite the contrary. They must be in favor of it and dependent on it. They must maintain the stance that it is not the judges but the law that determines which litigant wins and which loses, even when that is not entirely true. The invocation of law, however, will not always and forever persuade outsiders or litigants of the neutrality and independence of the courts if the substantive judgments of the courts too frequently or egregiously appear to favor certain parties or classes of parties or if the courts in some other way offend popular expectations of neutrality and independence. Courts typically invest enormous rhetorical effort in maintaining their reputations for neutrality and independence. The whole apparatus of judicial opinions is constructed to persuade the parties, the lawyers and ultimately the public that there are good legal reasons for the decisions reached that are valid quite apart from the fear or favor of the judges. The endless debate over judicial self-restraint is largely a debate about what actions by courts risk undermining the myth of neutrality and independence.

Courts get much of their political clout from a confusion that is endemic to legal thinking and is often signalled by the expression "rule of law". In its most primitive form that expression, and its non-identical continental equivalent rechts-staat, refers to the norm that the government must govern by actions in accord with existing law until it chooses

5 This is not the same question as "what are the conditions under which review can succeed". For instance, it may well be that no matter what its own behavior, a reviewing court cannot succeed in a regime without a competitive party system. The question here is what a reviewing court needs to do to succeed when the exterior conditions necessary for successful review are present and/or can be brought into existence by the court itself. 
to change that law. There is not even a hint in this concept that the law is neutral as between the citizens or independent of the will of the state. Quite the contrary, the suggestion is that the state is free to pursue its purposes, including fostering some social and economic interests and discouraging others, so long as it does so by promulgating general rules rather than engaging in piece meal, discretionary, perhaps secret, actions each aimed at a particular individual. The rule of law in this sense is supposed to be neutral and independent only at retail, not at wholesale. The law is not independent of the state. The state makes what law it pleases. The law is not neutral as between interests or powers, preferences or categories of citizens but instead favors whomever the law makers wish to favor. The rule of law requires only that the state's preferences be achieved by general rules rather than by discretionary (arbitrary) treatment of individuals. The pre-Civil War courts of South Carolina and the pre-Mandela courts of South Africa were guardians of the rule of law in this sense. Nevertheless, they hardly could be seen by the black persons who appeared before them as neutral and independent in relation to black-white conflicts of interest. The courts might (or might not) succeed in protecting blacks from arbitrary injury, but they certainly were part of a regime of repression of blacks which the courts would treat as valid so long as it proceeded by repressive general rules.

We have come, however, to load a second, higher law - human rights - meaning into the expression rule of law. Rule of law comes to mean not the rule of any law but the rule of good law and "good" in some sense beyond and above the immediate and particular purposes of those in political authority. The rule of law becomes the rule of norms that are just and true in some universal sense and thus of laws that are neutral and independent in relation to the particular immediate preference of the government. Then the rule of law comes to forbid not only arbitrary state behavior directed against particular individuals but bad state behavior even when the behavior is in the form of rules. This rule of law forbids both retail and wholesale bad state action. ${ }^{6}$

Courts are beneficiaries of this confusion of our thinking about the rule of law. Mostly courts only engage in retail rule of law insuring that government obeys its own laws until it changes them but quite unconcerned that the government's laws are far from neutral as between the owner and the burglar, the debtor and the creditor, the destitute and 
those capable of caring for themselves. And, of course, most of the time it is quite out of the question that a court should be independent of the preferences expressed in such laws. On the contrary, a court is to be their faithful servant. Nevertheless, we somehow believe that courts are not only courts of law but courts of justice, not only servants of government but its supervisors. As guardians of the rule of law, courts are somehow implicated in preserving the higher law and natural rights against even those inequities achieved through general rules promulgated and obeyed by government itself.

Constitutional courts obviously are special beneficiaries of this binary notion of the rule of law. They are both courts of law neutral and independent at retail and courts of law with a certain neutrality and independence toward the law itself.

Their real neutrality, plus the rhetoric, myth and a certain confusion about the nature of that neutrality may assist constitutional courts in exploiting their courtness in support of their policy making. It is not likely, however, that simply repeating loud and long that it is neutral and independent will be a successful strategy for a court that in its substantive judgments in division of powers cases consistently favors some of the power holders over others. In areal divisions, ${ }^{7}$ the central constitutional court must not appear constantly to favor the central government over the constituent parts or vice versa, and this is a particularly touchy point given that the central constitutional court is itself part of the central government. But even a constitutional court that consistently found in favor of the local governments and against its own would eventually lose its reputation for courtness. Not simply a rhetorical but some degree of real neutrality and independence in federal conflicts is one of the prerequisites of judicial success. If one tracks the "federalism" decisions of the U.S., Canadian and Australian constitutional courts and the European Court of Justice, very few periods will be found in which the central government or the states always win. The usual, simple minded story of the Marshall Court as centralizing and the Taney Court as "states' rights" is wrong. Both courts consciously strike a balance between national and state authority. ${ }^{8}$

7 By an areal division of power, I mean one between the constituent units and the central regime of a confederal, federal or similar system. See Arthur Maass, Area and Power (Glencoe, Ill., 1959).

8 Gibbons v. Ogden, 9 Wheat. 1 (1824); Willson v. Blackbird Creek Marsh Co., 2 Pet. 245 (1829); Cooley v. Board of Wardens, 12 How. 299 (1852). 
In areal division of powers systems the central constitutional court must also take some care not to appear to favor certain member states or groups of states over others. If it does maintain this general reputation for neutrality it can survive particular periods in which some of its decisions antagonize a particular state or states. The relationship of the ECJ to Germany is a current example.

Where constitutional courts operate in systems of central government division of powers, they are rarely going to need much by way of reminder of the need for even-handedness, for they are for the most part the pygmy between two giants quite capable of taking care of themselves. The U.S. Supreme Court in reality has played a very small role in the adjustments of constitutional power between Congress and the Presidency, those two institutions constantly making those adjustments by dealing directly with one another. ${ }^{9}$ The Court's relatively short list of "separation of powers" decisions do not consistently favor either side. Nor do they show much clarity or consistency of doctrine. The French Constitutional Council has not been remarkably pro-Presidential in spite of its Gaulist origins. ${ }^{10}$ The ECJ is in a more complex situation because of the marked inequality of the other central organs, with a very strong Council, a very weak Parliament and an uncertain relationship between the Council and Commission. As in the U.S., however, the Court has played a very secondary role, the Commission and the Council largely working out their own relationships. ${ }^{11}$ The Court has adopted a compromise position in its one major treatment of the powers of Parliament. ${ }^{12}$ The early history of the Russian Constitutional Court illustrates how quickly and easily a court may lose its judicial legitimacy in the struggle of executive and legislative titans.

9 Louis Fisher, The Constitution Between Friends: Congress, the President, and the Law (Princeton, N.J., 1978).

10 Alec Stone, The Birth of Judicial Politics in France (New York, 1992).

11 L. Tsoukalis, The New European Economy: The Politics and Economics of Integration (Oxford, 2nd ed., 1993).

12 Joseph Weiler, Pride and Prejudice - Parliament v. Council (European University Institute Studies, Florence, 1989). 


\section{Case-By-Case Decision Making}

A second institutional strength of courts in general that protects constitutional courts in particular is the low visibility, technical, incremental, case-by-case mode of judicial decision making. ${ }^{13}$ There is, of course, a certain amount of "abstract" constitutional review in many systems of constitutional law. Statutes are challenged on their face in a suit between one government organ and another. ${ }^{14} \mathrm{By}$ and large, however, it is American style cases and controversies judicial review that is central to most constitutional courts' experience. Even in civil law cultures where stare decisis is not formally acknowledged, constitutional law almost invariably becomes case law employing precedential reasoning even when the court's opinions do not formally announce such reasoning. ${ }^{15}$

Case-by-case decision making generates a complex of institutional advantages for constitutional courts particularly in regard to potential clashes with other political institutions such as other government organs, political parties and interest groups. Constitutional cases embed grand issues of politics and policy in particular disputes typically involving very small immediate stakes. Because the immediate stakes are low and the language and processes of litigation arcane, any particular constitutional case enjoys relatively low public visibility. Even when the doctrinal pronouncement of the court is strong, there is little by way of dramatic challenge to any power holder. The real impact of a particular decision will lie mostly in its future precedential operation rather than its immediate outcome. Those challenged may be, almost certainly are, aware of the real significance of the immediate decision, but they may

13 Martin Shapiro, Supreme Court and Administrative Agencies (New York, 1968) 7391.

14 Sweet, "What is Concrete About American Abstract Review?", Revue francaise de droit constitutionnel (forthcoming). Thus, in France the President of the Republic or the Senate may invoke the jurisdiction of the Constitutional Council to challenge the constitutionality of proposed legislation. In the EU the Commission, Council, member states and, under certain circumstances, the Parliament may invoke the jurisdiction of the ECJ against one another on abstract questions of treaty interpretation.

15 Langfried, "Judicial Policymaking in Germany: The Federal Constitutional Court", (1992) 15 West European Politics 50; Sweet, "Constitutional Dialogues: The Protection of Human Rights in France, Germany, Italy and Spain", in S. Kenney, W. Reisinger and J. Reitz, eds., Law and Politics in Cross-National Perspective (New York, forthcoming). 
have great difficulty in arousing their supporters over such a small event. Often they choose not to treat such a decision as a challenge and avoid a crisis. In electoral democracies political leaders usually operate within short time frames. A constitutional decision whose major real world impact will come after the next election can be ignored and may well better be ignored or downplayed rather than allowed to become an issue in the next election. ${ }^{16}$ Case-by-case decision making will usually allow courts some leeway in the timing of those decisions likely to cause controversy. Judges become skilled at turning cases aside on lesser issues. What is crucial here is the degree to which case materials as they are thrown up by the process of litigation allow the judges some capacity to combine particular fact situations involving particular parties and particular immediate outcomes with doctrinal pronouncements that have more, larger, longer term political impact. The matter is one of degree. All politicians have some control of timing. All resort to various "buy now, pay later" schemes. Case-by-case judicial decision making is, however, a particularly good ground for easing into major policy change both by announcing big new law in small cases and by moving small doctrinal step by small doctrinal step into big changes.

This step by step into big changes is not only a means of finessing political crisis and avoiding confrontation. There is a second important dimension. Case-by-case decision making contributes more to the institutional strength of courts than the strategic capacity to mix small immediate impacts with large, long-term policy initiation. Although incremental decision making does not guarantee success, it is a mode of decision making widely adopted by organizations operating in complex environments because of its capacity for risk reduction. All policy making, and particularly that of government, is fraught with unanticipated consequences. Large initial moves entail the risk of large losses. Consequently a strategy of proceeding one small step at a time, preserving the option of slightly changing direction as responses come in to each step taken, the famous error correction through feedback, is very likely to yield better results than double or nothing All political actors have the option of more or less incremental policy making most of the time. For courts too the matter is one of more or less. On occasion at least courts can take big policy steps if they want. Generally, however, they have the option of taking quite small steps. Their case-by-case mode of

16 Karen Alter "The Emergence of an Authoritative International Court in the European Union", (1996) 19 West European Politics 458. 
decision tends to keep them well within incremental bounds while legislatures are pushed in a nonincremental direction by the general and prospective nature of statutes. Courts are likely to be relatively sensitive, flexible and generally successful policy makers because their inherent decision making style is incremental. ${ }^{17}$

\section{Legal Epistemic Communities and the Strength of Constitutional Courts}

The policy making of courts is not only typically low visibility and incremental but is "technical" both in language and substance. Students of contemporary government have discovered epistemic communities growing like weeds everywhere. Because much of modern government involves the fostering and regulation of complex technologies, much of it has become technocratic. The British belief that empires should be run by profoundly ignorant people with second class honors degrees in classics has crumbled. Today government is increasingly government by expert. That means government by specialist. Specialists form separate communities, separated from the rest of us not only because they hold knowledge which the rest of us do not have, but because their members have in common the special perspectives that arise in the course of acquisition of that knowledge. Particularly since the atomic triumphs of one such community in World War II, we have become increasingly aware of, and suspicious of, our dependence on such communities.

Technocratic government by multiple communities of experts who represent their own peculiar preferences rather than those of people in general has come to be perceived as a threat to democracy. ${ }^{18}$ The relation of expert policymaking communities to political parties has not been so frequently noted. Epistemic communities have been more analogized to interest groups and associated with interest group "capture" of government regulatory organs. Such communities are treated as yet another set of actors in the complex dance of interest groups that constitutes the policy making mechanism of pluralist democracy. In the accounts of the relations between legislatures, political executives,

17 Shapiro, supra n. 13.

18 Weiler, "Eurocracy and Distrust", (1986) 61 Wash. L.R. 1131; Shapiro, "Judicial Activism" in S.M. Lipset, The Third Century (Stanford, Ca., 1979). 
bureaucracies, courts and interest groups that are commonplace in the study of contemporary regulatory politics, epistemic communities typically appear as yet another disintegrative force, yet another player challenging the discipline of responsible and accountable government in the public interest. The engineers want to build the strongest, the economists the most efficient, the architects the most beautiful, the bankers the most profitable bridge just as the bicyclists want one with a bicycle lane and the concrete industry one made of reinforced concrete rather than steel beams.

Although we may well have been losing faith in all of modern government, we particularly have been losing faith in political parties. Recent concerns with party corruption are only the final and rather superficial cause of dissatisfaction. In either majoritarian or pluralistic visions of democracy, political parties are the essential mechanisms for aggregating the multiple interests and preferences which left to their own devices would otherwise render representative government unworkable. Representative legislatures have generally been thought of as the centerpieces of democratic government. Only party discipline could generate policy product from such large, diverse assemblies.

Party democracy worked fairly well for distributive politics and even for many public interest issues. Parties did not appear to be very good mechanisms for regulatory politics. Regulatory politics has been a response to rapid technological development. Stable technologies to which society has had a long time to adjust do not appear to require government intervention. Where new technologies have a major impact which disrupts standing social arrangements, government intervention is a more or less natural response. It may well be true that a great deal of subtle government regulation lies below the surface of traditional agricultural societies, in part in the tax law and the operation of various government monopolies and in part in ostensibly private law of property, inheritance and trespass. But such regulation changes as slowly as pre-industrial agriculture changes and concerns matters that the common gentleman understands or at least thinks he does. New and rapidly changing technologies bring regulation to the front burner of politics, the steam engine and mechanical loom in England, railroads in the U.S. These matters require more than common knowledge. Regulation of high technology constantly dramatizes the view that people who know are superior governors to people who don't know. And knowing, at least scientific and technological knowing, does not fit well into party politics, for party politics are about advantage and preference 
and sheer numbers, not about knowledge. In the U.S. it was said "there is no Democratic or Republican way to pave a street", or run a railroad for that matter. Parties that seemed so good at aggregating interests seemed quite inappropriate for aggregating knowledge.

This point was quite clear by the end of the 19th century. Even democratic polities began to build up expert governmental enclaves at least ostensibly reserved against party politics: the independent regulatory commissions in the U.S., the grand corps in France and various ad hoc commissions and bodies of inquiry in England. Yet such devices were necessarily troublesome for party democracy. At first the solution was to constantly reassert the ultimate subordination of experts to democratic politicians as in parliamentary sovereignty and Presidential control of the executive branch. As this subordination came to appear increasingly illusory, both the U.S. and Europe became increasingly insistent on transparency and broad outside participation in technocratic policy making. Indeed, those goals of transparency and participation have long replaced fairness as the central goals of the proliferating administrative law on both sides of the Atlantic. ${ }^{19}$

That very growth in administrative law, however, signals our despair over political parties. Party government is no longer seen as capable of controlling and, more importantly, orchestrating regulatory policy making necessarily dominated by experts. Instead, the demos must be provided with both direct observation of and participation in the regulatory palaver of the experts. If the demos cannot beat the experts, it can at least join them.

Regulatory as opposed to distributive politics brings the problem of parties to the fore in another way as well. Both majoritarians and pluralists essentially deal in process rather than substantive norms. The question is not whether some government policy is substantively good or bad, whether the fish live or die under the purported protection of the clean water statute, but whether the statute was the product of majority will or the fair bargaining of the interested groups. Since the mid-twentieth century there has been increasing concern with whether the fish live or die. It is not enough that, although they inadvertently die, the protective policy was made by majority vote or pluralist compromise. While political parties do fairly well at distributing farm subsidies and welfare state entitlements, they do not inspire much

19 Jurgen Schwarze, European Administrative Law (London, 1992); Shapiro, "The Giving Reasons Requirement”, (1992) U. Chi. Legal Forum 179. 
confidence that, unaided, they will come up with the correct cures for environmental degradation. Where correctness rather than tit for tat is at issue, there again raises its head the proposition that those who know something ought to be in control. Even more fundamentally, the suspicion arises that when in pursuit of the good, something more than counting heads is involved. As the western world perceives itself as moving from an agnostic politics of interests to a politics of values, particularly in environmental, health and safety matters, parties appear less useful. Good at aggregating interests, they do not look good at aggregating values. Or rather values are not to be aggregated but pursued. The word "deliberate" is liberally scattered about current political and legal theory as a flag signalling that we do not want party politics as usual but do not know what we do want, except that we do know we want to talk about "the good" rather than the election returns. ${ }^{20}$

Epistemic communities take on some of the integrative tasks that parties are losing. They aggregate persons of somewhat differing interests around a core of common knowledge. The whole point of epistemic communities is, of course, that they combine knowledge, interests and values in curious ways. Commonality of knowledge in and of itself leads to a certain convergence of interests and values. Those who share a body of knowledge and the discipline of learning it will have to some degree come to share common perspectives. Two economists are more likely to see the world in the same way than an economist and a poet. Two economists also have a common interest in the flourishing of economists and the discipline of economics not shared by an economist and a poet. And a poet is likely to be less concerned with efficiency than an economist. On the other hand, one economist may be a liberal democrat working for a labor union and the other a conservative investment banker.

We have tended to emphasize the commonalities in epistemic communities as we try to persuade people of their existence. It is, however, their combination of commonalities and divergences that makes them most interesting. For they can use their commonalities to achieve aggregation of their divergences. The economics community may do far better than the parties at arriving at an agreed international trade policy.

20 Shapiro, "Of Interests and Values: The New Politics and the New Political Science", in Marc Landy and Martin Levin, eds., The New Politics of Public Policy (Baltimore, 1995). 
Those interested in law and courts have become alert to epistemic communities as impinging on the work of courts and legislatures. They have tended to neglect, however, that courts themselves enjoy many of their institutional strengths by virtue of being embedded in one of the oldest and most flourishing of the epistemic communities, lawyers. Perhaps this link between lawyers and judges would be self-evident were it not for the fact that judges have typically been appointed by and become members of the government, and thus apparently are separated from "the bar". The link probably is most obvious for the English speaking world. In England itself judges were indeed appointed by and served at the pleasure of the Crown until 1700 . Nevertheless the judges very clearly were a senior committee of the barristers guild. The common law practice of drawing judges from among senior esteemed practitioners creates a union of bench and bar. In a very real sense both the law and the courts belong to the lawyers. The world of Islam is the same, where the political authorities must appoint the khadis from among the community of the learned. Among the major legal systems of the world, the Confucian is unique in preferring judges without legal training and prohibiting law practice.

The civil law tradition presents the intermediate case. Judges are law graduates but typically enter the judicial service immediately after their schooling and stay in it for life. Unlike the common law world, the practising bar is not the very center of the profession from which a few members are sent off into judicial or government service. Instead, in civil law states the bar tends to be the least prestigious of a professional triumvirate of government service, judicial service and private practice. Moreover, on the continent law as a body of learning grew up as one of the three basic university subjects along with medicine and theology and so was less an esoteric, specialized body of knowledge than a common educational base for lay society, at least after university education became commonplace for the political class.

Yet for all this, lawyers constituted a quite distinct social element even if law graduates did not. And in spite of early career divergence judges were lawyers. Even if the judges did not perceive the existence of courts and their jobs as totally dependent on the existence of law practice, the continental bar certainly thought of its existence as totally dependent on the existence of courts. And no one, least of all the government, questioned that judges were members of, and must satisfy the norms of, the legal profession. 
Law is a community not only in its shared body of knowledge and its particular mode of thinking perceived by its members as both unique and superior. It is also an economic community in which the material self-interest of every member is dependent on the proper functioning if not of every other at least of many others. And it is a social community in which the prestige of each one and each part is dependent on the prestige of the other individuals and parts. If courts are in low repute, practitioners obviously suffer both financially and socially, but even government lawyers see their importance eroded vis-à-vis other government officials. Academic lawyers must be added to this picture. For all its claims to free standing academic prestige, the law professorate's position has been greatly dependent on both the prominence of courts and the health of the profession as a whole, a point easily illustrated by the pitiable state reached by the legal academy under communism.

This interdependence and mutual support of lawyers and judges is so deeply embedded in the routine legal system that it is hardly noticeable. The relationship is more salient when we move to constitutional courts. The legal profession in the U.S. has enjoyed an enormous boost in prestige from American constitution worship and has, in turn, rallied to the support of the Supreme Court when it has come under attack. On the continent, academic constitutional lawyers in nations without constitutional judicial review were hardly at the top of the academic pecking order. In France those academics carefully nurtured and cultivated the new Constitutional Council and today seek to proclaim its constitutional law as fully worthy to stand beside the codes, ${ }^{21}$ which, of course, really means above them. And in a very real sense what they are claiming is that they have moved from being anomalous to being the leading law professors in France. Joseph Weiler has emphasized the central importance of legal academe, the judges of the national courts and a specialized bar in the legitimation of the European Court of Justice. ${ }^{22}$

Constitutional courts are courts. They speak the lawyer's language. They provide the stream of cases that drive the lawyer's mill. They are a source of lawyer income and lawyer prestige. Lawyers are their gate keepers and their conduit to the lay world. They are staffed by lawyers.

21 See Thierry Renoux and Michel de Villiers, Code Constitutionnel (Paris, 1994).

22 See Weiler, "Journey to an Unknown Destination: A Retrospective and Prospective of the European Court of Justice in the Area of Political Integration", (1993) $31 \mathrm{~J}$. of Common Market Studies 417. 
Judicial "craftsmanship" ultimately is judged by the norms of the lawyer's craft. No one can really understand or even keep track of the judges' incremental decision-making except lawyers. Lawyers are the opinion leaders of their public constituency. The epistemic community of law has an enormous self-interest in defending constitutional courts, most basically in proclaiming their courtness. ${ }^{23}$ When constitutional courts enjoy great success, their success rubs off on all lawyers and all courts. When they are under attack, all courts and lawyers are under attack. Here again institutional choices tend to become self-enforcing. If judges and lawyers persistently and consistently proclaim that a constitutional court is not really a court at all, they may succeed in separating the constitutional court's fate from their own. Once they begin to acknowledge a constitutional court as a court, they will have little choice but to come to its defense which becomes a defense of themselves.

From the outsiders' perspective the embeddedness of constitutional courts in lawyer communities generates the same paradox as other epistemic communities. To the extent that we wish to exploit the expertise of those communities so as to govern complex matters wisely and efficiently, we must yield some priority to their particular preferences and projects. To the extent that we go beyond granting such communities government access and actually incorporate them directly into the apparatus of government, we yield them even greater priority. Courts as government institutions directly incorporate lawyers into government. Courts as incremental decision makers declaring policy in the course of litigation incorporate themselves into the practice of law. Constitutional courts elevate this entanglement to the highest levels of government policy making. If we choose constitutional courts we choose not only the government of judges but the government of lawyers.

And the lawyers will praise and defend this government.

\section{Division of Powers and Rights}

My argument so far has been that if the demos chooses to partially solve its principal agent contracting problem by choosing a division of powers government contract that engenders boundary conflicts between 
parts of government and chooses the conflict resolving mechanism of courts, it must take courts as they are with their inherent tendency to make rules and their impressive institutional capacity for self-defense. Today, constitutional courts are more often engaged in rights than in division of powers business. There are two ways of approaching this rights business. One is to treat it as an inevitable concomitant of division of powers, that if you buy the junk yard dog to protect the separation of powers junk, you can't keep it from roaming into the rights part of the yard as well. This may be true for one of two reasons. Either the dog has an inherent tendency to roam or someone wants to lure him into the rights piles.

The histories of constitutional courts support one or both of these versions of the division of powers story of rights. The U.S. constitution begins as a division of powers document. The Bill of Rights is added to supplement the division of power constraints that have been proposed for the new, feared, central government. The Supreme Court confines itself almost exclusively to division of powers business until well after the Civil War. It becomes involved in rights only after long and vigorous pressure from a powerful property rights lobby. ${ }^{24}$ Created explicitly to deal with newly constituted division of powers, the French Constitutional Council eventually discovers, quite miraculously, that there is a judicially enforceable bill of rights in the French Constitution. ${ }^{25}$ Exactly the same thing can be said about the European Court of Justice. Miraculously the Court discovers a bill of rights somehow lurking in the European Communities treaties. ${ }^{26}$

It may be that constitutional courts are so much courts of law and, at least in contemporary times, law is so much involved with rights that constitutional courts, by their very nature, will necessarily become involved with rights even if they have been established to deal with separation of powers. Or alternatively, it may be that constitutional courts are not inherently attracted to rights but are inevitably pushed into rights by strong elite and popular pressures. Either way, if you buy a separation of powers court, you get a rights court.

The second approach to the current rights business of constitutional courts is direct rather than through the division of powers. The demos may choose to establish constitutional judicial review precisely because

26 See Paul Craig and Grainne de Burca, EC Law (Oxford, 1995) 286-298. 
it wishes to use judicially enforced rights as an independent means of constitutional limitation on government. ${ }^{27}$ Constitutional regimes of rights pursue quite a different logic than those of division of powers. Division of powers regimes are attempts to create self-enforcing contracts. Each part of government will block breaches by the others with the constitutional court resolving conflicts that arise over these blocking moves. Constitutional rights, judicial review regimes do not aim at selfenforcing contracts. Quite the contrary. They anticipate that the government will from time to time seek to breach the contract and that the contract will be enforced against the government through litigation in the constitutional court. Division of powers cases do not occur when there is a clear and persistent majority because such a majority will eventually control all the divisions. Division of powers may pit national majorities against local majorities or momentary legislative majorities against a President elected by a different momentary majority. As the New Deal story in the United States suggests, however, clear majorities will soon end division of power conflicts by dominating all the divisions. Thus division of powers courts are not likely to confront persistent majorities.

To put the matter only slightly differently, constitutional courts doing division of powers business are more easily able to maintain their connection with the most basic rule of law notions, and the specific kind of judicial neutrality that goes with such notions, than are courts doing rights business. In division of powers cases a constitutional court is in effect saying, "we do not set ourselves against any government policies. Our government, as a whole, may do anything it pleases, so long as each part of government does the parts that the constitution says it should do. We the courts police only the process. We are neutral as to the policy outcome".

Judicial review constitutional rights regimes, on the other hand, specifically contemplate judicial confrontations of majority preferences. The contract does not enforce itself. The Court must enforce it against powerful, united, majority forces. Of course such a confrontation does not always occur. A thin majority of the moment may form as a product of complex and fragile log rolling in which various interests have been

27 Italy is a centralized country with parliamentary sovereignty. Its constitutional court is involved almost exclusively in rights cases. The European Court of Human Rights is exclusively a rights court. 
intricately compromised and balanced. A constitutional court may pull one card out of this house of cards and see the whole thing collapse rendering successful counterattack on the court impossible. Or the house may have collapsed of its own weight before the court intervenes. Nevertheless, rights enforcing courts are likely to confront firm antirights majorities from time to time. Indeed that is what they are there for.

Moreover, for all the romantic international human rights talk, no one has forgotten that rights are emphatically stated interests, that when majority will faces minority rights, one of the things that is going on is a confrontation between two sets of interests and the deciding court is not only protecting rights but choosing among interests. Rights are about substance as well as procedure. The majority is not always told that it can have what it wants if it can put all the procedural pieces together. It is told instead that, sometimes at least, it cannot have what it wants.

As we all know perfectly well, the standard response that once upon a time a constitutional majority wanted to limit the possible substantive preferences of all subsequent legislative majorities, and the constitutional court only acts in favor of that majority against the current one, has not proven entirely satisfactory. To keep repeating that certain interests are not merely interests but rights that constitutional courts are especially enjoined by the constitution to protect, is merely to keep repeating precisely what is being contested. For the majority is not likely to admit that it wishes to invade such rights. Instead, it will assert that the court that is thwarting it has chosen to translate certain naked economic, social or political interests into constitutional rights in order to favor those interests over majority interests. It is precisely this unending and unendable majoritarian debate that I wish to avoid recapitulating here..$^{28}$ What is clear is that no matter how many prescriptions for a delicate balance between judicial activism and judicial self-restraint are offered, constitutional courts cannot resist going down the rights path.

28 See, e.g., John Hart Ely, Democracy and Distrust (Cambridge, Mass., 1980); Alexander Bickel, The Least Dangerous Branch (New Haven, 2nd ed., 1986); Charles Black, The People and the Court (New York, 1960); Ronald Kahn, The Supreme Court and Constitutional Theory (Lawrence, Kansas, 1994). 
Indeed, in spite of the endless and subtle writing seeking to reconcile rights and majoritarianism, the real issue that troubles us lies elsewhere. It may be that late in the 19th and early in the 20th century there was a clear choice of pure majoritarianism, under the name parliamentary sovereignty, in many Western nations. It is gone now even in England and France where it was most prominent. There is virtual agreement on rights throughout the West, some would argue throughout the world. The issue is not majority vs. rights, but judicial policy making discretion. If constitutional rights are to be judicially protected, judges must make some policy decisions. Will judges exploit their rights jurisdiction to make policy decisions more appropriate to government organs subject to electoral mechanisms of popular accountability?

As with all judicial review, some degree of policy discretion is inescapable in constitutional rights cases because of the interpretation trap - that whoever is assigned to interpret text to some degree makes the text. Rights provisions of constitutions must be interpreted by courts if they are to be enforced by courts. And it is difficult and perhaps even undesirable to word such provisions very narrowly. So constitutional rights interpreters receive more than the minimum elbow room.

The standard interpretative elbow room is not really the main problem. The high degree of judicial discretion found in constitutional rights cases stems instead from our attitudes toward rights themselves. None of us believes in absolute rights. There are instances in which two constitutional rights conflict. The conflict cannot be resolved without treating at least one of them as less than absolute. That situation is, however, a mere anomaly. The basic problem is that no one believes that an individual right should be protected no matter how much damage to the rest of us the vindication of that right requires. Because U.S. rights jurisprudence has been so long and vigorous, it provides endless examples of this phenomenon, particularly in relation to the right that Americans treat as the most absolute, freedom of speech. At the rhetorical level there is shouting fire in a crowded theater or publishing the sailing times of troop ships in time of war. At the practical level we get the exceptions of obscenity and libel and commercial speech from full First Amendment protection, as well as the exception for advocacy of the overthrow of the government as speedily as circumstances will permit, the clear and present danger rule for street corner oratory, and various limitations on the exercise of speech rights on private property and public property devoted to special uses with 
which free speech would interfere ${ }^{29}$ Indeed, American constitutional law of speech is far more about the permissible limits on speech than about freedom of speech.

The nonabsolute nature of constitutional individual rights is vividly painted in the American case law, but it is obviously also emblazoned in the texts of most constitutions as well. The U.S. constitution protects against unreasonable search and seizure. The German Basic Law provides that many of its rights may be limited by "general legislation". The European Convention on Human Rights typically provides the right in the first paragraph and the qualifications on that right in the second paragraph of each provision. Ultimately the rights provisions of all constitutions come down to the proposition that government may not limit a right unless it has a very, very good reason to do so. All rights provisions come down to reasonableness provisions. If we then empower courts to enforce rights provisions what we do is authorize them to decide the reasonableness of the acts of other parts of government.

Such reasonableness judgments are hardly foreign to courts. They make them in contract, commercial law and tort cases all the time. But in most areas of law judicial findings of reasonableness can be rested on prevalent community practice and limited by standing lines of precedents involving hundreds of past decisions in closely comparable cases. Constitutional rights reasonableness decisions, particularly where statutes are involved, are usually more sui generis and more abstract and global in character. What is or is not reasonable rests far more on predictions of future choices and events than of well understood patterns of past behavior. Ultimately, a reviewing court must go through exactly the same calculations the legislator did. The point is not that constitutional courts sometimes blatantly serve particular interests and causes but that policy making is an inevitable and inescapable part of reasonableness judicial review and rights review is necessarily reasonableness review. This was, of course, the well-known position of Hans Kelsen and Learned Hand who opposed rights review for precisely this reason. ${ }^{30}$

Here again we are back to the junk yard dog. The demos or the majority is free to buy or not buy the dog, but it cannot escape institu(Cambridge, Mass., 1995).

30 Hans Kelsen, "La Garantie Jurisdictionnel de la Constitution", (1928) 44 Revue de Droit Public 197; Learned Hand, The Bill of Rights (Cambridge, Mass., 1958). 
tional realities. Once bought, the dog will bite. And it must be said in looking at the contemporary world "once bitten, twice shy" does not apply. The more the rights dogs bite, the more of them seem to get purchased. The eagerness for rights manifests itself not only in the constitutional but the statutory field, with a proliferation of statutory entitlements. The rhetoric of rights becomes so appealing that it becomes attached to public policy preferences like environmental protection that would appear to be so pressing that they would not need rights talk to further dramatize them. Trees have rights.

Lawrence Friedman fairly persuasively traces the growth in concern for rights to the growth in the pervasiveness of modern government. ${ }^{31}$ Rights provide individual protections against a growing governmental threat. The powers of democratic governments grow about as fast as those of authoritarian governments. Our first instinct is to grant new government discretion to deal with new problems. What principally distinguishes democratic states is the long-term tendency to bring each of those new discretions under the rule of law. One of the means of accomplishing that subordination of discretion to law is the creation of individual rights given priority over that discretion. Such rights are most effective against discretion if provision is made for their judicial enforcement. In this sense the demos chooses rights not as a reservation to the authority of its own majority against its own minorities but as yet another solution to the principal agent problems generated by the contract of government. It is not majority rule versus minority rights but government discretion held within the terms of the contract by judicially enforced rights. Two additional phenomena must be noted. The first is the well-known shift from negative to positive rights. The second is the growing propensity to employ rights as weapons in interest group struggles.

The move to positive rights is an attempt to assign relatively fixed, long-term priority to certain categories of public expenditure. ${ }^{32}$ It is precisely in the realms of taxing and spending that the people tend to vest the greatest discretion in government and to control that discretion not by law but by elections. To move taxing and spending under a judicially enforced regime of rights is a very fundamental alteration of the nature of democratic government. In Europe it has been socialists

31 Lawrence Friedman, Total Justice (New York, 1985).

32 See S. Leibfried and P. Pierson, eds., European Social Policy (Washington, D. C., 1995). 
who have most vigorously counterposed positive social rights to bourgeois negative rights, but socialists have never been particularly fond of judges. More generally, judges do not seem very attractive candidates for the making of taxing and spending decisions. Such decisions seem to demand a degree of general coordination beyond the case-by-case decision capacities of judges. They also involve so strong an element of sheer political distribution that substantial judicial involvement would be fatal to claims of judicial neutrality. And even if we confine ourselves to welfare state minimums rather than substantial equality of material benefits, judicial enforcement of positive rights promises to entangle judges in endless quarrels over how much and what quality food, clothing, housing etc. is even minimally enough. So, in spite of all the current talk about dismantling the welfare state, it is not positive social rights as such that are really at issue but the judicial enforcement of those rights. Rights judicial review is certainly beginning to move into the area of positive rights in many constitutional regimes. It remains to be seen whether much deeper judicial involvement in the who gets what questions of the "new property" will entail the extreme judicial crisis that the U.S. Supreme Court's involvement with the old property once did. For the moment, however, judicially protected negative rights retain center stage.

The second attendant phenomenon worthy of attention is what my colleague, Robert Kagan, calls "adversarial legalism" ${ }^{33}$ While along one dimension constitutional rights are universal or democratic reservations against the discretion vested in a government agent, along another they become devices for furthering one particular interest against another. Litigation and the threat of litigation grounded in constitutional and statutory rights has become a commonplace of contemporary interest group politics. Such adversary legalism may certainly pose a threat to the efficiency of democratic government by increasing transaction costs. If one subscribes to pluralistic theories of democracy, however, adversary legalism poses no particular threat to democracy as such. It is true that some decision making power is shifted to nonelected judges, but pluralist democracy is full of nonelected decision makers and/or decision makers elected by some people who make decisions about the fates of other people. The mechanisms for much of adversary legalism were put in place by legislative majorities who have authorized and

33 Robert Kagan, "Adversarial Legalism and American Government", in Marc Landy and Martin Levin, The New Politics of Public Policy (Baltimore, 1995). 
facilitated judicial review as a check on the administrative discretion they have been granting. We are back to the junk yard dog again. Legislative majorities could sharply limit judicial review if they chose some other mode of limiting executive discretion. If you are a postpluralist, "deliberation" sort of democrat, then a case can be made out that litigation fosters deliberation. And, with some notable exceptions, constitution makers appear to have believed in a sort of Adam Smith approach. Leaving the way open to constitutional rights enforcement through individually motivated litigation creates a litigation market in which the competitive selfish interests of individuals are harnessed to achieve the general good. The more adversarial legalism, the more the general interest of the demos in solving its agency problems through rights creation will be enhanced by individual law suits seeking to vindicate constitutional rights.

On the whole, I find the arguments I have been making in this paper more convincing on the divided powers than on the rights front. And I believe that constitutional courts that must claim legitimacy purely on the basis of rights jurisdiction are on shakier ground than division of powers courts. Nevertheless, I think the same basic argument applies. The constitutional law of rights is not so much a matter of majority will versus minority rights as of the people as principal versus their agent government. In this context as in others, if the principals choose a particular institution, they must take the institutional bitter with the institutional sweet. If the principal has chosen judicially enforceable rights as a device for curing agency problems, there is no reason that judges should feel guilty about what courts institutionally do and must do to make such a device work, create a good deal of constitutional law of their own in the course of litigation. The real question is, as always, not yes or no, but how much.

\section{Democracy and Judicial Institutions}

In summary then, my general argument runs as follows. Let us assume that the constitutions of democratic states are themselves democratic, that is enacted by the will of the demos. The constitution is a contract between the demos and government. The demos as constitution maker faces the classic principal-agent problem when it establishes government by contract. How is the contract to be enforced on the agent? One option is a degree of self-enforcement through division of 
powers. If that option is chosen conflicts between parts of government are anticipated, indeed invited, but such conflicts if unresolved result in the destruction of the whole contractual arrangement. Thus the constitution makers may resort to a standard institution of conflict resolution - a court. If they do, to some degree, they must accept the inherent characteristics, practices, strengths and weaknesses of the institution. If they elect courts for conflict resolution, they must accept some law making by courts and a certain capacity for judicial selfdefense of its law making activity. The issue of whether such law making and self-defense are somehow anti-democratic or antimajoritarian is uninteresting. If the demos chooses the institution, it chooses the judicial law making and judicial self-defense. Reciprocally, courts that owe their existence to democratic institutional choice must act prudently or the choice may be withdrawn.

Not exactly the same argument applies to rights enforcing constitutional courts. Here constitution makers have not engineered a situation of conflict between parts of government and then set up a court as resolver of those conflicts. Instead, they have deliberately created a conflict between courts and the rest of government or chosen courts as a direct enforcement instrument of the principal on its agent. Again as an institution the court is saying if you choose us you must accept our law making. But here the court is acting not as a conflict resolver but as a direct protagonist against the rest of government and thus loses its ties to the most basic legitimacy or appeal of courts, their usefulness as conflict resolvers. In division of powers cases, the division and thus the conflicts would exist whether the court existed or not. If the court is abolished, the conflicts continue and the need for resolution continues, now without a resolution mechanism. So in division of powers matters there is a big reason not to abolish constitutional courts. The elimination of judicial review would necessitate a total restructuring of the constitution. A rights court is far more dispensable than a division of powers court. Without a rights enforcer a democratic government can go on. A rights court must be even more prudent than a separation of powers court. A constitutional court that is both a rights and a division of powers court is in the best position because even if its decisions along one of these two dimensions engenders majority opposition, its institutional integrity may be defended by those who want it to act along the other.

I would like to proceed from this rather long preliminary argument to a brief application of it to one of the most successful of the post-World 
War II constitutional judicial review courts, the European Court of Justice, and to the problem of the "democratic deficit" that is said to confront the whole regime of which the Court is a part.

\section{Origins and Structure of the European Communities (Union)}

While I shall advert later to the ECJ's achievement in "constitutionalizing" the treaties that are the founding texts of the Communities and the Union, I do assume for purposes of my general discussion that the treaties were constitutions when written. For certain purposes it may be important to distinguish between federal constitutions, on the one hand, and on the other, treaties in which some national sovereignty is surrendered to transnational organs themselves constituted by the treaties and themselves endowed with the power to make law directly applicable to the signatory states. ${ }^{34}$ For my purposes here I believe the distinction is unnecessary. I shall treat the member states as the founding fathers of a more or less democratic constitution. Among the possible distinctions I will treat cavalierly is the distinction between a constitution ratified by a popular election and one ratified by sovereign states as states which are themselves more or less democratic. The Communities and Union treaties were ratified by the unanimous agreement of the member states as states acting through their elected governments. They created a government regime in which those democratically elected governments sent representatives to a law making organ which itself made decisions either unanimously or under a majority rule that took the differing populations of the members into account. Thus I will treat the whole matter as a democratic constitution arrived at democratically.

On one dimension the EC-EU is more democratic than most of the constitutional regimes that we normally assume to be democratic. In most such constitutions the founders, as opposed to the framers or drafters, are the "people" in whose name the constitution is legitimated or more concretely the people as manifested in some sort of electoral ratification mechanism either representative or direct. After this one initial act, the demos tends to fade away into some sort of tacit consent giver. In the EC-EU the ratifiers are the people as manifested in

34 Weiler, "The Community System: The Dual Character of Supranationalism", (1981) 1 Yearbook of European Law 268. 
democratically elected representative bodies of the member states. Those member state governments do not fade away into tacit consent but must give their continuous active consent in order for the new constitutional system to sustain itself over time. In this instance we speak more literally of what the founders chose and what they have to, or are willing to, live with than we can in most constitutional situations.

With these preliminary caveats, which to some will be bottomless pits or unbridgeable gorges, we move on to a story of constitutional founding and sustaining which I also believe is fairly simple but every step of which is actually in contention among both scholars and politicians.

At the end of World War II, two motives lay behind transnational moves in Europe. One was security, the need to prevent renewal of the cycle of Franco-German wars. The second was economic, the need to create an economic entity large enough to compete both in domestic and foreign markets with the American colossus. Various international law treaty regimes had in the past failed to achieve either security or economic cooperation in Europe. What appeared necessary was the institutionalization of transnational organs that were far more than League of Nations style debating societies or permanent international negotiations cites. These new institutions must have some level of independent and effective law making and implementation powers. Although a United States of Europe was no doubt the ultimate goal of some, the main thrust from the beginning was that the institutional arrangements of the Communities should be sui generis, neither an "international organization" nor a federal state. ${ }^{35}$

The law making process established was indeed a strange one. Laws may only be proposed by the Commission which is a body of transnational administrators whose appointments are greatly influenced by the member states but who are not representatives of particular states. Commission proposals may then be enacted into law by the Council which consists of representatives of the member states. Laws concerning some subjects must be approved unanimously by the Council. Others require only majority voting with some states casting more votes than others on the basis of population. The ECJ may strike down laws enacted under the Treaties which are not in accord with provisions of the Treaties. The European Parliaments' role is largely advisory although it has some

35 Stephen Weatherill, Law and Integration in the European Union (Oxford, 1995) Ch. I. 
veto powers. I am not concerned here to give a full account of the legalities or changes in them over time. This sketch will suffice for my analysis of the ECJ and democracy.

\section{The Institutional Strengths of the ECJ}

The Treaties provide that only the member states or organs of the Communities may invoke the jurisdiction of the Court directly. They may do so to challenge the actions of the organs of the Communities or of a member state that may violate the Treaties or any secondary community legislation enacted under the Treaties. In addition, Article 177 provides that should an issue of Community law arise in a case in a court of a member state, that court may take reference to the ECJ which will provide an authoritative interpretation of the Community norm at issue. ${ }^{36}$ Thus the framers of the Treaties established a Court that is unique. Like the U.S. Supreme Court this is a court of general jurisdiction, that is, it hears not only cases of alleged treaty violation but all cases arising under community treaties and laws. It enforces treaty provisions related both to division of powers between the member states and the Communities and between the various governmental organs of the Communities. It practices concrete, case-by-case review of legislation after it has been promulgated. Unlike the U.S. Supreme Court it generally does not hear cases brought by individuals. Moreover, the Treaties contain no equivalent to the U.S. Bill of Rights so that the Court at first did not concern itself with rights questions, with a few exceptions such as gender discrimination.

The uniqueness of the ECJ adds to rather than subtracts from its institutional strengths as a higher law judicial review court. We can speak here much more clearly of the framers' or ratifiers' intentions than we can in connection with judicial review courts embedded in general all purpose governments. The member states that came together to form the Communities did so against the background of a long series of failed treaty regimes designed to foster European security and economic relationships. Clearly they wanted more than just another static treaty. And they clearly wanted something more than a treaty regime with a Hague style international court of justice. They wanted

36 H. G. Schermers, C. Timmermans, A. Kellerman and J. Watson, Article 177 EEC: Experiences and Problems (North Holland, 1987). 
a treaty regime firmly under their individual and collective control that nonetheless was capable of making and enforcing free trade rules, at the very least a customs union with teeth. And they wanted more than that. They wanted a regime that was capable of positive economic development initiatives of at least a limited kind as well as negative responses to national trade barriers. It was precisely because the member states were prepared to cede some positive power to first the Coal and Steel and then the Economic Community that they bothered to set up an elaborate division of powers central regime. ${ }^{37}$ If the principal is giving the agent no power, he need not worry about writing a self-enforcing, that is a division of powers, agency contract. Moreover, in arranging the areal division of powers, the member states were aware of the natural tendencies of a cartel, which is what a customs union is, to break up under the pressure of individual member cheating. They were also aware of the great success of the U.S. Supreme Court in policing the American free trade area, particularly the "negative commerce clause cases" in which the Supreme Court struck down state laws interfering with interstate commerce. ${ }^{38}$ Thus the constituters of the ECJ clearly intended it to do what a higher law court appears most suited to doing, resolving border conflicts in division of powers systems. Although such resolutions might involve the Court's coming head to head with a member state or with the Commission or Council, it would do so in a context in which the most powerful political actors, the member states themselves, wanted other member states to obey the free trade rules, wanted the central organs to check and balance one another and wanted a judicial mechanism to enforce these divisions of power.

The boldest decisions of the ECJ were those holding that the Treaties and the secondary legislation enacted under them were supreme over national constitutions and law $^{39}$ and had "direct effect" in the member states, that is, became part of the domestic law of the member states creating individual rights and duties that could and would be

37 Weatherill, supra $\mathrm{n}$. 35, at Chs. I and II.

38 See Blasi, "Constitutional Limitations on the Power of States to Regulate Goods in Interstate Commerce", in Terrence Sandalow and Eric Stein, Courts and Free Markets (Oxford, 1982).

39 Case 26/62, NV Algemens Transporten Expeditie Ovderneming van Gend en Loos v. Nederlandse Administratie der Belastingen [1963] ECR 1; Case 6/64, Flaminio v. Costa Enel [1964] ECR 585. 
vindicated in domestic litigation. ${ }^{40}$ It is the combination of these decisions that constitutes one of the great bootstrapping operations of any court, anywhere, anytime: the translation of the Community treaties into a "constitutional text" for the Communities. ${ }^{41}$ In international law, treaties generally create only state rights, duties and obligations toward one another and do not enter the domestic law and create individual rights, duties and obligations for citizens of the signatory states unless "domesticated" by national legislation enacting the treaty provisions into national law. Even when so domesticated, the treaty provisions are not normally considered by domestic courts to be supreme over the constitutions of the member states or over national statutes enacted subsequent to the domesticating statute. On the other hand, at least under the U.S. and German models, a federal constitution is supreme over the constitution and laws of the member states and directly vests rights, duties and obligations in individual citizens of the federation that must be vindicated by both state and national courts. It is in this sense that, in spite of their names, the ECJ turned the treaties into a constitution.

Upon closer examination, this great constitutionalizing feat of the ECJ is not such an extreme act of judicial independence as it might appear. The signatories did want the treaties to be supreme in the sense of imposing judicially enforceable obligations on their fellow states. In a treaty basically concerned with economic activities of states with large private economic sectors, formal supremacy without direct effect would have been very unsatisfactory to the members themselves. The member states were well aware that a free trade area would not be achieved by the mere abolition of formal customs duties, that all sorts of other member states' laws had an equivalent effect to tariffs in the creation of national trade barriers. If the member states had to domesticate the abolition of each and every one of these trade barriers by national statute in order to effectively abolish them, and if they could then be renewed by subsequent national legislation, the whole system would have been unworkably sticky with the greatest rewards to whatever state stuck it out the longest. The treaties were meant to be supreme and would not work unless they had direct effect. Undoubt-

40 Van Gend en Loos and Costa Enel, supra n. 39; Case 39/72 Commission v. Italy [1973] ECR 101; Case 41/74 Van Duyn v. Home Office [1974] ECR 1337.

41 Case 294/83, Parti Ecologiste "Le Verts" v. European Parliament [1986] ECR 1339; C-2/88 Zwartveld [1990] ECR I-3365. 
edly, the member states had not clearly worked out in their own minds exactly the constitutionalizing that occurred, but they clearly intended to go beyond the standard treaty to some kind of institutionalized free trade regime with real teeth. That is what they got. In fact, the direct effect decisions of the Court did not evoke any fire storm of opposition from the member states.

Another unique feature of the institutional arrangements of the Communities enhanced the normal institutional strength of the Court of Justice as court. The founding member states were sufficiently aware of the potential political power of courts that they made a special attempt to divide and disburse the judicial power of the Communities. They were aware that where, as in the U.S., a single highest court was established for a regime, as opposed to two or more such courts, as in France, the single court had an enhanced survival potential. A single court exercising both higher law judicial review powers and the general legal powers of a final appeals court enjoys an advantage when its higher law powers generate unpopular decisions. Particularly in a federal state, but actually in any state large enough to require a substantial number of trial courts and some intermediate appellate courts, a single highest court is essential to maintain regime-wide uniform interpretation of statutory law. If there are two highest courts, one for statutory interpretation and one for constitutional interpretation, uniform statutory interpretation continues even if the constitutional court disappears. Where there is a single highest court, it can, to some degree, quiet down opposition to itself as an institution by pointing to its necessary role in maintaining legal uniformity. Thus the ECJ is essential to the legal efficacy of the Communities. Even if the ECJ's higher law vetoes of member state or Communities laws should engender heated opposition, the Court itself could not be abolished without a totally unacceptable loss of legal uniformity across the wide and nationally divided domain of the Communities.

In full awareness of this central highest court advantage, the member states created a peculiar appeals system for the Communities with echoes of the French cassation system of weakening highest central appeals courts. Under Article 177 of the Treaties, a national court encountering an issue of European Communities law may suspend its proceedings and make reference to the ECJ for its authoritative interpretation of the Communities text at issue. Having received this clarification, the national court would then recommence its proceedings leading to its final judgment. Thus the application of the authoritatively 
interpreted text to the particular facts of the case, the final judgment of which party wins and which loses, and the remedies granted are retained by the national court.

In this way the powers of the ECJ were obviously diminished from what they might have been. A strong judicial division of powers was created. But something else, and something probably largely unanticipated, happened as well. Article 177 could be, and very frequently has been, used by the ECJ to enforce EC law on recalcitrant member states by bold interpretation of the treaties and secondary norms. Under 177 , however, these ECJ challenges to member state authority take the ultimate legal form of a member state's own national court declaring that it has acted unlawfully. The remedy for this unlawful act is applied against the member state by its own national court. Direct confrontation between the ECJ and the member state is avoided. More importantly, a member state that wishes to refuse compliance to an ECJ interpretive ruling would have to do so by refusing to obey its own national court's decision and remedy, thus appearing to violate the most fundamental national tenants of rule of law. The division of judicial power actually gave the ECJ unusually powerful leverage over the member states. ${ }^{42}$ It cannot be a mere coincidence that the ECJ's leading decisions on direct effect and supremacy which "constitutionalize" the treaties come in 177 cases as do many of its other most important decisions. And 177 feeds into the institutional strengths of the Court based on low visibility, low particular stakes and case-by-case decision making. For 177 decisions are formally often decisions of minor, lower level national courts in cases where the stakes are small except from the perspective of the particular private parties to the litigation.

Finally, the unique law making process established for the Communities also enhanced institutional powers inherent in the ECJ as court. All other things being equal, an interpreting court has more power where the legal text it is interpreting is more generally worded. That is one of the reasons constitutional judicial review courts typically are unusually powerful or rather, why, if a constitutional review court is otherwise secure, its powers will be multiplied. Constitutions are Rulings - the Paradox of Success: A Revisionist View of Article 177EEC", in Schermers, et al, supra n. 36; Anne Marie Slaughter, Joseph Weiler, and Alec Stone, eds., The European Court and the National Courts (forthcoming). 
usually broadly worded with an eye to maintaining their long-term survival under difficult-to-anticipate, changing circumstances. The same is, of course, true of the Communities' treaties. Also in general, a court's interpretative powers grow the more difficult it is for the text enactors subsequently to amend the text to "correct" judicial law making by interpretation that the initial law makers do not like. Constitutions and treaties are usually deliberately made difficult to amend because typically they are packed with guarantees of protections for those ratifiers who fear that in future they may be in weak bargaining positions within whatever new political process is created by the proposed new higher law. Without a difficult amending clause, such guarantees would be meaningless and the needed ratifiers would not ratify. The Communities' treaties reflect these dynamics. Thus the ECJ is a powerful interpreter because, like many higher law judicial review courts, it interprets a generally worded, difficult to amend, text.

Until recently, the Council could enact secondary Communities law, and thus amend such law, only by unanimous vote. Obviously, a unanimity rule makes it difficult to pass new laws amending existing ones. Such a rule also tends to produce generally worded legislation because general wording facilitates compromises and papers over differences thus making it easier to arrive at unanimous decisions. Joseph Weiler has correctly made much of the fact that the unanimity rule made member states less leery of judicial expansions of Community competencies because it insured that each member retained an ultimate veto power over threats to its vital interests. ${ }^{43}$ But the unanimity rule also enhanced the interpretive powers of the ECJ over secondary legislation.

\section{The ECJ and Democracy}

Thus the ECJ has the institutional strengths typical of any court and the special institutional strengths typically associated with constitutional judicial review courts. In addition, it has the strength of a highest general appellate court. And it has some special strengths that derive from the unique institutional arrangements of the EC. Of course, the ECJ also has the general weaknesses of courts, no purse or sword and 
no direct electoral connection to the citizens in a democratic milieu where such a connection is the major generator of perceived political legitimacy. The unique institutional arrangements of the EU, however, tend to reduce the institutional weaknesses of the ECJ in relation to democracy. It is not the ECJ but the whole EU that is said to suffer from a democratic deficit. The Commission has no direct electoral connection with the citizenry. The Parliament does, but the connection is very imperfect, and the Parliament has only a very small participation in EU law-making. The Council consists of representatives of the member state governments which in turn are democratically elected, but this electoral connection is one step removed. And, until recently, the unanimity rule undercut any Council claim to democratically represent the EU citizenry as a whole, given that the vote of one nation with a small population could block the policy initiatives of member states containing the overwhelming majority of Union citizens. The ECJ does experience the democratic deficit encountered by any nonelected court. Unlike most higher law review courts, however, it is not in the position of thwarting the will of the directly elected representatives of the people. The ECJ's claim to independence and neutrality is enhanced by an appointment process that scatters the judicial selection process among the member states each controlled by a different national party or coalition rather than concentrating the appointment power in a single, highly partisan chief executive. To democratic qualms the ECJ can respond with both the standard "we're not supposed to be democratic" and "compared to whom".

The basic argument I am making about the ECJ is again: "If you buy a junk yard dog ..." If the Court serves the function the demos wants, resolving conflicts generated by a complex division of powers regime, then the demos must accept some measure of independent judicial power. Ultimately the matter is one of cost benefit analysis for the demos. Does the institutionalization of a higher law review court reduce the principal agent problems of the demos with the rest of government sufficiently to justify some principal agent costs to the demos as principal to its judicial agent?

\section{The ECJ and Fostering Democracy in the EU}

Obviously this cost benefit analysis is effected not only by the general advantage to the demos in terms of judicial conflict resolution of bound- 
ary disputes but by any specific enhancements to the demos' control over agents that may be generated by the Court's decisions. That is the central message of such justly famous works as John Hart Ely's Democracy and Distrust ${ }^{44}$ and Vincent Blasi's "Checking Value" of the First Amendment. ${ }^{45}$

How much have the ECJ's decisions contributed to democratic control over Union decision making. The basic answer is "not much". But that answer is too simple. The framers did not think much in terms of standard representational democracy, only enough to provide an advisory Parliament as window dressing. The governments of the member states were democratically elected. The Communities were essentially an international organization. While the Commission, particularly in its role as executive of the Coal and Steel Community, would have a strong policy making role, ultimately the Council controlled the Communities and the Council was the member states. In that sense, talk of a democratic deficit has always been misguided. Under Council control, the Union is as democratic as it is supposed to be and need be. Europeans have not been fans of direct democracy. Their national governments are representative democracies. Most are allegedly pure parliamentary systems. In reality, however, everyone knows that in these parliamentary states today, it is not the parliament that controls the cabinet but the cabinet that controls the parliament. It is not the representatives of the people who rule but the representatives of the representatives of the people. It is precisely the same cabinet members who rule the national parliaments who rule the Council. So the basic institutional arrangements of the Union is not really far removed from the actual working democracy of the member states. Surely the democracy deficit does not lie simply in the same cabinet member who makes policy at home going off to Brussels to do it along with the cabinet members of other EU states.

The democratic deficit, if it exists, exists not at the level of institutional schematics but in an existential situation in which policy is made indeed by representatives of representatives but with very low levels of transparency and direct popular participation. In this sense, democratic deficit is just a specialized EU term for what is often called the

45 Blasi, "The Checking Value in First Amendment Theory", (1977) American Bar Foundation Research J. 521. 
contemporary legitimation crisis. That crisis involves the erosion of popular support for even representative democratic governments precisely because, in the conditions of bureaucratic, technocratic, complex modern government, electoral mechanisms do not sufficiently control representatives or the representatives of representatives and the representatives of representatives do not sufficiently control government. Along these dimensions the EU may appear particularly vulnerable.

The legitimation crisis is about participation, transparency, expertise, responsibility and scale and boils down to a perception that the distance between citizens and government has increased. EU government in fact is not very large, the total number of EU bureaucrats excluding translators being less than that of many European city governments. It is, however, perceived as distant, in Brussels rather than in one's own national capital. This distance is particularly important in terms of government regulation of business, and I will return to it in a moment.

The EU has even more of a responsibility or accountability problem than national governments. Party electoral compétition has been the principal means of democratic accountability in the West. As unsatisfactory as that seems to be at the moment, the EU is missing even this because there really are no EU political parties, only national parties keyed to national issues. Only in a few member states have any EU issues been contested among national parties. Collective cabinet responsibility is also attenuated in the EU. While the Council always consists of representatives of each state, theoretically under the control of the cabinets of their respective states, the Council is different people on different days. When the Council meets on an environmental matter it consists of member state environmental ministers, when on agriculture matters, the agriculture ministers and so on. Twelve environmental ministers meeting together and alone are likely to reach somewhat different environmental policy conclusions than the environmental ministers of each state could have gotten out of their own cabinets where finance and trade ministers would have sought to curb environmental enthusiasms.

Popular suspicion of technocrats is part of the legitimation crisis everywhere. In the Union, the Commission has been the particular target because it is an expert bureaucracy with more institutional independence than exists for the expert bureaucracies of any of the member states. 


\section{Transparency, Participation and Regulation}

The greatest EU deficits are obviously in the realms of transparency and participation. The EU law making process is complex, unique and understood hardly at all by most Europeans. It is extremely difficult to follow what is going on there. It is also extremely difficult to participate in what is going on in a new, unique and distant political process. Of course, transparency and participation are closely related. You cannot participate unless you know what is happening and why, and participation is itself one of the principal ways of knowing what is happening.

How much does the ECJ itself exhibit these problems? How much is it doing to alleviate them for itself and for the rest of the EU? Like most courts, the ECJ is very expert, well outside the normal channels of democratic responsibility and quite untransparent. Like most courts it is small in scale, but like most high courts it is distant. Only government organs rather than individuals and groups may normally take cases directly to the Court. Article 177 references bring private interests there indirectly. As with all courts, participation is expensive, but, once in, parties are treated as equal. The Court issues unsigned opinions more or less explaining its decisions, but does not report votes or publish dissents or concurrences.

It is in the realm of administrative law that courts typically have the greatest opportunity to increase the transparency of and participation in government policy making processes, to bring the expert under lay control and generally increase government responsibility. ${ }^{46}$ Regulation is a particularly contested topic in the EU. So the administrative law of regulation is a major area in which the Court might act to ease the legitimation problems of the EU.

Along some dimensions the EU has been an enterprise driven by deregulatory motives. ${ }^{47}$ Changing the regulatory arena from the member states to the Communities itself provided some opportunity to overcome long-standing national regulatory inertias particularly because the shift occurred during a time period in which free market ideas n. 3.

47 Renaud Dehousse, The Institutional Dimension of the Internal Market Program, (Florence, 1989). 
have been in vogue. ${ }^{48} \mathrm{EC}$ politics is even more elite driven than European national politics and so a particularly promising ground for antiregulatory corporate elites. ${ }^{49}$ The very purpose of the European Coal and Steel and then the European Economic Community was to increase economic efficiency which regulation is claimed to undermine. At the very least, the substitution of one community-wide rule for twelve national rules is, in a certain sense, deregulatory. On the other hand, in the U.S., the EU and globally the enthusiasm for deregulation in the 1960 's, '70's and '80's was accompanied by a huge new wave of environmental, health, safety, civil rights and consumer protection regulation..$^{50}$ The very laissez-faire move from public ownership to privatization creates more regulation as the enterprises shift from internal to external government supervision.

The theory and institutions of EU regulation have been subjects of much debate. ${ }^{51}$ National regulation in Europe has generally been corporate in style particularly as compared to the U.S. Cooperative rather than adversarial relationships between the regulator and the regulated have been the norm and neither have wanted transparency or public participation. The legitimacy of expert decision making rather than democratic legitimacy has been stressed. National regulatory policy has certainly been a matter for party politics, but regulatory implementation has been somewhat insulated from partisanship. ${ }^{52}$

48 Lonbay, "The Single European Act", (1988) 11 Boston College International and Comparative L.R. 31; Cameron, "The 1992 Initiative: Causes and Consequences", in Alberta Sbragia, ed., Europolitics (Washington, D.C., 1992).

49 Fligstein and Brantley, "The Single Market Program and the Interests of Business", in B. Eichengreen and J. Frieden, eds., Politics and Institutions in an Integrated Europe (Berlin, 1995); Schneider, Dang-Nguyen and Werle, "Corporate Actor Networks in European Policy-Making: Harmonizing Telecommunications Policy”, (1994) 32 J. Common Market Studies 473.

50 Steven Vogel, Freer Markets, More Rules: The Paradoxical Politics of Regulatory Reform in Advanced Industrial Countries (Ithaca, N.Y., 1996).

51 See G. Majone, Regulating Europe (London, 1996).

52 See Joseph Badaracco, Loading the Dice: A Five Country Study of Vinyl Chloride Regulation (Boston, 1985); Steven Kelman, Regulating America, Regulating Sweden: A Comparative Study of Occupational Health and Health Policy (Cambridge, 1981); David Vogel, National Styles of Regulation: Environmental Policy in Great Britain and the United States (Ithaca, N.Y., 1986); Susan Rose Ackerman, Controlling Environmental Policy: The Limits of Public Law in Germany and the U.S. (New Haven, 1995); Sally Kenney, For Whose Protection? Reproductive Hazards and Exclu-sionary Policies in the United States and Britain (Ann Arbor, 1992); Ronald Buckman, Sheila Jasanoff and Thomas Ilgen, Controlling Chemicals: The Politics of Regulation in Europe and the United States (Ithaca, N.Y., 1985). 
Community regulation has broken into these patterns not so much because of moves to deregulate but for reasons of scale or distance. French business executives, themselves former French civil servants, no longer do their regulatory business over Paris lunches with French bureaucrats who grew up in the same neighborhood and went to the same schools. They now must go to Brussels and deal with a German or Italian bureaucrat. The changes must not be exaggerated. Styles of interaction do not change overnight. One can get a good meal in Brussels too, and somewhere in the Commission one can find an old classmate or officemate to help. But the old corporatist intimacy is reduced. The regulators and the regulated are no longer so much insiders together. A little distance arises as indicated by the growth of a flourishing Brussels lobbying industry. ${ }^{53}$ You do not need to hire a lobbyist to watch the bureaucrats when they are your constant companions. As business elites begin to feel like outsiders, they begin to distrust the inside experts and themselves become more interested in transparency and participation.

Distrust of experts also begins to arise along national dimensions. By its very nature regulation is a realm of experts, but now there are French experts and English experts. Of course, the regulated have long known how to marshall their own experts against the regulator's experts, but in the EU government experts from different governments are themselves sometimes at odds.

Even more generally, technocratic government - government by experts - has come under increasing suspicion. A significant theme of post-modern, post-industrial societies is the theme of professional deformation, that people who know more and more about less and less lose perspective, that their expertise generates ideology which in turn distorts their expertise and that their professional projects carry large elements of self-interest and self-serving. The EU introduced more distanced expert regulation at a time when the bloom was off the experts. ${ }^{54}$

There are also counter tendencies. Precisely because of the legitimation crisis of democratic governments in general and the supposed

53 S. Mazey and J. Richardson, eds., Lobbying in the European Community (Oxford, 1993); Anderson and Eliassen, "European Community Lobbying", (1991) 20 European J. of Political Research 173.

54 Shapiro, "The Problems of Independent Agencies in the United States and the European Union", (1997) 4 J. of European Public Policy 276. 
special democratic deficit of the EU, there is some hope that expert legitimacy can substitute for democratic legitimacy. The U.S. pioneered in taking regulation "out of politics" through the creation of the independent regulatory commissions. The British politically neutral executive class of the civil service, the French grand corps, and the German concern for the rechts-staat, exhibit similar dimensions. Particularly in the face of the various scandals that have plagued political parties of late, independent, nonpartisan agencies, commissions and tribunals are the order of the day and governments of experts often appear to offer at least moments of respite from political corruption.

Partly because the regulation of high tech enterprise seems to necessitate it, and partly to bolster legitimacy, the EU has created a number of technocratic arenas of regulatory policy making. First came the Eurocracy, the expert politically neutral - both in the non-party and nonnational sense of neutral - civil service of the Community centered in the Commission..$^{55}$ Then, following a quite natural political dynamic, the permanent staff of the Council, COREPER, developed its own expertise to counter that of the Commission. ${ }^{56}$ Then there came the multiplication of the so-called independent agencies of the Union engaged in expert enterprises in areas like drug licensing and environmental data collection. ${ }^{57}$ The Council has also created the "comitology process" by which committees of experts are delegated law making powers to write the detailed requirements of regulatory statutes. ${ }^{58}$ Indeed, a strong general argument is made that the cure for the democratic deficit of the EU is to depend on alternative legitimacy, the legitimacy of experts. ${ }^{59}$

The arguments over technocratic government are further complicated by the increasing complexity and diffusion of the regulatory process itself and the increasing sophistication of our knowledge of that process. Technocracy once denoted rule by commands of government experts. Today we see that rule by experts is rarely rule by government Parliament (London, 3rd ed., 1995) 179-185.

56 Weatherill, supra n. 35, at 60-61.

57 Alexander Kreher, ed., The New European Agencies (Florence, 1996).

58 Joerges and Neyer, "From Intergovernmental Bargaining to Deliberative Political Processes: The Constitutionalization of Comitology", (1997) 3 European L.J. 273; Vos, "The Rise of Committees", (1997) 3 European L.J. 210.

59 Majone, "The New European Agencies", (1997) 4 J. of European Public Policy 260. 
experts alone but more typically rule by epistemic communities, a set of persons sharing a common body of specialized knowledge, some inside and some outside the government. These epistemic communities may be highly compact or relatively diffuse. They may dominate or be dominated by economic, political or social clienteles. For instance, nearly all the experts in testing new drugs may be employees or grantees of the drug industry. Nearly all the experts on mass vaccination may be officials of government public health services. Specialists in industrial safety may be spread among government agencies, corporations and labor unions. The move from government expert to epistemic community itself is in part a result of greater concern for broadening the scope of participation in government and makes government more transparent, but more transparent only to non-government experts not to the citizenry at large. ${ }^{60}$

Rule by expert has also expanded from government command to include all sorts of "soft law" from advisory bulletins and press conferences to mediations and jawboning. Here too, the phenomena are both cause and effect of greater concern for transparency and participation. Greater transparency and participation for the whole set of experts, however, typically is bought at the cost of even greater diffuseness and complexity that further excludes laymen.

Thus we know that in the EU today regulation is a process and product of groups of experts, the number and names of whom constantly change, interacting through complex, interlocking channels of communication, some formal, some not, some governmental, some not, toward decisions, non-decisions and partial decisions expressed as legal rules, government advice, common or model practice, announcements of public policy, consensus and/or negotiated settlement. Frequently, the art of politics becomes the assignment of a given policy question to one epistemic community or another or to an epistemic community rather than an agency of government, or the structuring of a government organ to either incorporate or exclude particular epistemic communities. Both the new EU "agencies" and the comitology process seem to be intended to be situations in which the epistemic communities swallow up government. Both enormously increase the transparency of and participation

60 See Christian Joerges, Karl-Heinz Ladeur, Ellen Vos, eds., Integrating Scientific Expertise into Regulatory Decision-Making (Baden-Baden, 1997); Renaud Dehousse, Regulation by Networks in the EC: The Role of European Agencies (Florence, n.d.) 
in government by nongovernment experts, thus increasing technological legitimacy. Both do so at the cost of making the EU even more difficult to understand for the nonexpert.

Quite apart from the dynamics of expertise, another complexity arises in EU regulation. Implementation is by the member state administrative bureaucracies. Each of those bureaucracies operates within its own administrative traditions, practices and national bodies of administrative law and under its own system of judicial control of administration when it implements EU regulatory policies. The European Union treaties contain only rudimentary administrative law provisions. No administrative law code has been enacted by the Communities. ${ }^{61}$

At the moment national implementation of Communities regulation operates almost entirely on a "don't ask, don't tell" basis. It is considered a great accomplishment that member state courts and bureaucracies now formally acknowledge their duty to obey and implement Community law. ${ }^{62}$ No one is anxious to undermine this great victory for integration by inquiring too closely about what is really going on and discovering the national variations that inevitably must exist. The ECJ in many ways follows the French model, but more the model of the Council of State than the Court of Cassation. The French have a powerful administrative case law built up by the Council of State. Having more or less completed the basic case law of free movement of goods that was essential to the establishment of the Union's free trade zone, the next great task of the ECJ may be to provide an administrative case law for both the free trade and regulatory implementation programs that are largely in the hands of the member state bureaucracies.

In doing so, or rather if it seeks to do so, the ECJ will experience pressures toward participation and transparency on the one hand, and pleas on the other for the substitution of expert discretion for democratic choice. And many of the players in this arena are aware of the lurking perils of American style adversary legalism in which everyone can and does sue everyone else about everything all the time.

. Indeed, in the area of administrative law applicable to the central organs of the Communities, this dynamic is already at play. One of the

61 Harlow, "Codification of EC Administrative Procedures? Fitting the Foot to the Shoe to the Foot", (1996) 2 European L.J. 3; Shapiro, "Codification of Administrative Law: The U.S. and the Union", (1996) 2 European L.J. 26. 
few specific administrative law provisions of the Treaties is Article 190 requiring that all community organs give reasons for their actions. Such a giving reasons requirement can and was initially read by the ECJ in a very minimalist way. The Court was probably aware of the American experience with such a requirement. The American Administrative Procedures Act of 1946 provides that new agency rules be accompanied by a "concise and general statement of basis and purpose". Initially American courts accepted even the most cryptic agency statement as sufficient. Eventually they came to require the agency to provide a complete explanation of its actions including responses to every point raised in opposition to the proposed rule and argument as to why it was the best rule that could be made. For many years the ECJ turned back American style claims that reasons given were inadequate if they did not respond to each and every opposing point raised. The increasing European pressures for transparency and participation that we noted in discussing the "democratic deficit", like American pressures earlier, are now leading the ECJ in the American direction of requiring more complete reasons including responses to points raised against a proposed rule. While the ECJ may never go as far as the Court of Appeals for the District of Columbia has, it has now broken with its earlier line of decisions and is requiring more responsive reasons from the Commission. ${ }^{63}$

Where national organs of member states act to implement Communities' policies, they are organs of the Communities bound by the administrative law of the Communities. But there is little or no such law. So long as "don't ask, don't tell" continues, there will be little perceived need for such law. "Don't ask, don't tell" can't last forever. Over the long haul national disparities in implementation are going to seriously disrupt Union economic integration. One response is going to be administrative law litigation. Both the "independent agency" and comitology processes of the EC organs themselves are already engendering strongly voiced demands for more transparency and non-expert participation which almost inevitably will soon turn into litigation. Academic sources are busy now trying to draft administrative law for the Communities by applying comparative methods to the existing administrative law of the 
member states. ${ }^{64}$ They take their lead from the ECJ itself which, having discovered that there is an implied bill of rights in the treaties, although none is explicitly stated, has undertaken to build up the constitutional rights laws of the Communities through case-by-case comparative law endeavors to constitute community individual rights from the rights law of the members. ${ }^{65}$ It seems probable that, fed by the academics through the briefs, the ECJ will create an administrative law as well as a constitutional rights law.

Certainly if the Commission must give adequate reasons for what it does, the new independent agencies, which are essentially modes of expanding the regulatory powers of the Commission without expanding the Commission, must give good reasons too. And if commission experts and agency experts must give good reasons when they make law, why shouldn't comitology experts bent on filling in the details of the law. And if the final details of the law inevitably must be filled in by national experts implementing Community law, why shouldn't they as well give good reasons, especially when one nation's implementers seem to be doing things differently than another's.

In general, the European Union is passing into a stage of consolidation of the free market combined with new environmental, health, safety and consumer protection regulation, much of which potentially clashes with free market goals. It is a stage at which implementation will be more critically scrutinized. The eastward expansion of the EU will particularly exacerbate implementation concerns because of the enormous difficulties post-Leninist states seem to experience implementing anything. Here again the institutional paradox arises. Judicial review appears to be a very appropriate and convenient way of checking on agency implementation of policies made by their legislative principals. Courts can demand participation and transparency. Courts can correct the professional deformations of epistemic communities wielding governmental implementation powers. ${ }^{66}$ Having chosen courts, however, we are subject to the institutional characteristics of courts. Once the EU chooses courts to review administrative action, it is inevitable that courts themselves will be major players in deciding the balance between

64 Schwarze, "Developing Principles of European Administrative Law", (1993) Public Law 229; Spetses Conferences, “Toward a Unified Judicial Protection in Europe?", (1997) 9 European Review of Public Law 523. 
democratic and expert legitimacy chosen for the Union. If democracy chooses courts, then the demos must eagerly wait to find out whether those courts choose democracy.

\section{Conclusion}

The general argument here is easily summarized. If the demos or whoever acts for them, chooses constitutional arrangements that encourage institutional conflicts, they will be under strong pressure to create courts to deal with those conflicts because courts have a good institutional record as conflict resolvers. Courts as conflict resolvers inevitably turn into courts as law makers and exhibit certain institutional strengths in defending themselves as law makers counter-balancing their institutional weaknesses, namely, their lack of purse or sword. Higher law judicial review courts have certain strengths as courts per se and certain other strengths as higher law and division of powers policing courts. The question of whether such courts are or are not democratic is not very relevant. If the demos chooses them, it chooses them warts and all. If they sufficiently well deal with the principal agent problems of the demos, it is worth it to the demos to be bitten by them once in a while. Although themselves very much part of government by the few, and protected by a powerful community of experts, such courts can choose either to foster more democratic or more expert government. The ECJ exhibits this pattern. It has been extremely successful at policy making, even at constituting and defining its own role in the regime of which it is a part. Shortly, it may become a principal actor in deciding the balance between democratic and expert claims of legitimacy for that regime. 